Food Webs

March 2016, Volume 6, Pages 19-28

http://dx.doi.org/10.1016/i.fooweb.2015.12.002

http://archimer.ifremer.fr/doc/00301/41203/

(c) 2015 Elsevier Inc. All rights reserved.

\title{
Feeding strategies of co-occurring suspension feeders in an oligotrophic environment
}

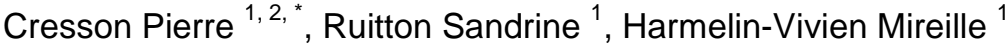

\author{
${ }^{1}$ Aix-Marseille University and Toulon University, Mediterranean Institute of Oceanography (MIO), \\ CNRS, IRD, UM 110, F-13288 Marseille, Cedex 09, France \\ ${ }^{2}$ Ifremer, Centre Manche - Mer du Nord, BP 669, F-62321 Boulogne sur Mer, France \\ * Corresponding author : Pierre Cresson, email address : pierre.cresson@ifremer.fr
}

\begin{abstract}
:
Suspension-feeders predominate in the vast majority of the coastal marine benthic ecosystems, with several species co-occurring at low spatial scale. Understanding how these species cope with competition for trophic resources has been the core of numerous studies, mostly in coastal shallow systems where food supplies are diverse and abundant. Oligotrophic systems have received less attention. The aim of the present study was thus to investigate the trophic relationships established between 9 suspension feeders collected in an oligotrophic zone (Bay of Marseille, French Mediterranean). Species displayed similar isotopic ratios, consistently with the use of one main source, identified as nanophytoplankton and diazotrophic bacteria as the $\delta 15 \mathrm{~N}$ values were low, in contrast to interspecific differences generally observed. The seasonal variations of the isotopic ratios and isotopic niche indices were explained by differential sorting abilities, higher for bivalves than for ascidians and the polychaete Chaetopterus variopedatus. The present results demonstrate that resource availability in oligotrophic systems is a major driver of trophic competition. It precludes a general conclusion about suspension feeders trophic patterns drawn exclusively from highly productive systems, and stresses the need for an extensive assessment of those patterns in a vast range of ecosystems.
\end{abstract}




\section{Graphical abstract}

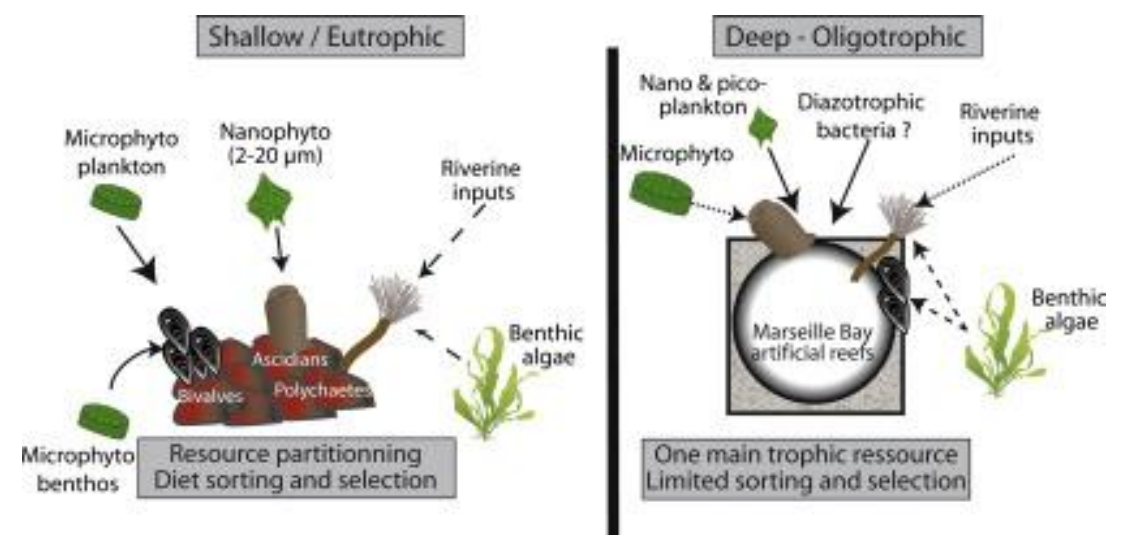

Keywords: Suspension feeders, Isotopic niche, Mediterranean, Oligotrophy, Resource sharing mechanisms 


\section{Introduction}

Interspecific competition is one of the major mechanisms driving biological functioning, at both individual and community level (Connell, 1961; Schoener, 1974). In marine benthic communities, space has long being considered as the dominant limiting resource but food resource limitation by co-occurring species is also recognized as a predominant driver of individual and community functioning (Buss and Jackson, 1981; Côté et al., 1994; Dubois and Colombo, 2014; Svensson and Marshall, 2014). Resource partitioning and trophic plasticity are commonly considered as strategies established by co-occurring organisms to limit the adverse effects of trophic competition (Gutt, 2006; Riera, 2008; Kang et al., 2009; Lefebvre et al., 2009). Suspension-feeders predominate in most benthic ecosystems, where they are considered as engineer species, since they create new biogenic habitats and alter the tridimensional structure of the community (Gili and Coma, 1998; Ribes and Coma, 2005). They also drive bentho-pelagic coupling, as their strong filtering abilities alter the organic matter (hereafter OM) fluxes and provide trophic subsidies for other benthic consumers, directly or through OM pools (Gili and Coma, 1998; Dubois et al., 2007b; Cheung et al., 2010; Bracken et al., 2012). Most benthic suspension-feeder communities are composed of several co-occurring species which have to cope with competition at a small spatial scale (Kang et al., 2009; Yakovis et al., 2012; Richoux and Ndhlovu, 2014; Dubois and Colombo, 2014). Understanding how trophic competition drives interspecific relationships and OM fluxes provided case studies to document interspecific trophic competition and resource sharing mechanisms.

Suspension-feeders are of major commercial interest and are cultivated worldwide. Documenting how the biomass production of cultivated species might be affected by trophic competition with wild or invasive species has thus been widely investigated (Lesser et al., 1992; de Montaudoin et al., 1999; Riera et al., 2002; Decottignies et al., 2007; Dubois et al., 2007b, 2007c; Riera, 2007; Xu and Yang, 2007; Kang et al., 2009; Lefebvre et al., 2009; Lacoste et al., in press). Patterns in natural uncultivated systems received less attention until recently (Bode et al., 2006; Schaal et al., 2010; Colombo et al., 2013; Dubois and Colombo, 2014; Richoux et al., 2014). In both cases, studies have been conducted in coastal shallow eutrophic ecosystems, where trophic subsidies available to suspension feeders are diverse and abundant. Stable isotope analyses were powerful tools to discriminate the relative contribution of these sources. The premise of this technique is that the isotopic ratios of a consumer are dependent upon the ratios of its diet with a trophic enrichment factor (hereafter TEF) between consumer and diet. Since $\mathrm{C}$ and $\mathrm{N}$ isotopic ratios differ between $\mathrm{OM}$ sources, measuring isotopic ratios of suspension-feeders enables identification of the major contributing source. These studies demonstrated that, although receiving the same mixture of suspended matter, co-occurring suspension feeders are able to be largely plastic in their diet and to partition the food resources to 
limit competition (Coma et al., 2001; Riera et al., 2002; Riera, 2008; Marín Leal et al., 2008; Lefebvre et al., 2009; Dubois and Colombo, 2014; Richoux and Ndhlovu, 2014; Richoux et al., 2014). Size and nutritional quality of the particles appeared to be the main factors explaining the difference in resource use, since species differ in their filtration and retention mechanisms and in their ability to sort and select particles before ingestion and then to digest them. In bivalve species, laterofrontal cirri are key organs located in the gills. They beat alternatively to generate a current and to collect particles, with $100 \%$ retention efficiency for particles up to $4 \mu \mathrm{m}$. In addition, labial palps can sort and select particles, and reject particles of low nutritional interest in pseudo feces. Some species, such as Mimachlamys varia, lack such cirri, and possess only prolaterofrontal cirri, causing a less efficient retention of particles (Dubois and Colombo, 2014; Riisgård and Larsen, 2010; Ward and Shumway, 2004). The annelid Chaetopterus variopedatus and the ascidians use a similar system, based on the active pumping of water by muscular pistons in $C$. variopedatus or through the inhalant siphon in ascidians, and the retention of particles on a mucous net, constantly ingested and renewed. This system is efficient to retain $100 \%$ of particles down to 0.5 to $1 \mu \mathrm{m}$ for $C$. variopedatus and to $1-3$ um for ascidians (Flood and Fiala-Médioni, 1982; Jumars et al., 2015; Petersen, 2007; Riisgård and Larsen, 2010). Seasonal variation of the available food sources was also demonstrated to be a crucial factor, as suspension-feeders use the predominant component of the suspended OM (Coma et al., 2001; Lefebvre et al., 2009; Richoux and Ndhlovu, 2014). Nevertheless, since patterns in deep and oligotrophic environments are poorly documented (Ribes et al., 2003; Elias-Piera et al., 2013; Lesser and Slattery, 2015), it is rather difficult to provide generalized trends regarding the suspensionfeeders' trophic mechanisms. The deployment in the bay of Marseille of the largest Mediterranean artificial reef system in 2007-2008 provided a major opportunity to assess the effect of oligotrophy on suspension-feeders trophic mechanisms. Artificial reefs are efficient scientific tools to question ecological hypotheses concerning suspension-feeders, since they provide a man-made ecosystem where there are few technical and ethical issues related to the sampling of natural communities (Miller, 2002) and they are mainly colonized by suspension-feeders (Rouanet et al., 2015). Thus, the aims of the present study were to assess the trophic relationships between co-occurring suspensionfeeders and to answer the following questions. How does food scarcity in an oligotrophic system affect resource sharing? Are food-sorting mechanisms still applicable in this context? How do suspension-feeders cope with the seasonal variation of food resources?

\section{Material and methods}

In the bay of Marseille, artificial reefs were deployed in 6 triangular-shaped groups named "villages". Sampling was carried out on two "metal basket" artificial reefs in the north (village V3, $30 \mathrm{~m}$ depth) and the south (village V6, $25 \mathrm{~m}$ depth) of the deployment zone, with V6 reef located close to the 
shore and to the mouth of the Huveaune River (Fig. 1). Metal basket reefs were large, high structures $\left(6 \mathrm{~m}\right.$ high, $\left.187 \mathrm{~m}^{3}\right)$ of which the architectural complexity was increased by the addition of devices such as concrete cubes or oyster bags (i.e. bags filled with dead oyster shells deployed inside artificial reefs), creating shelter for small cryptic organisms. More details on the architectural structure of the bay of Marseille's artificial reefs can be found in previously published works (Charbonnel et al., 2011; Rouanet et al., 2015). The bay of Marseille is considered oligotrophic, with chlorophyll-a concentrations always lower than $0.5 \mu \mathrm{g} \mathrm{L}^{-1}$ during sampling periods (SOMLIT data, http://somlitdb.epoc.u-bordeaux1.fr/bdd.php?serie=ST\&sm=6, P. Raimbault, pers. comm.; Cresson et al. 2012). In summer and winter 2012, all suspension-feeding species were collected by scuba diving, manually scraping organisms settled on artificial reef structures or sampling the oyster bag fauna. Back in the laboratory, all organisms were sorted, identified and dissected to remove all calcified parts, such as bivalve shells or polychaete tubes. Species collected at one season only were discarded, resulting in a dataset of 9 species (Table 1). No major differences in the size of individuals were detected during field sampling, leading to the analysis of one size class for each species. This would limit the intraspecific size effect but may cause interspecific differences, if the age of the individuals differs between species. Organisms were stored dried, before freeze-drying and grinding with a mechanical grinder.

Four OM sources were considered to determine the fluxes fuelling suspension-feeders and to assess couplings between pelagic, benthic and terrigenous ecosystems. Benthic primary production was considered by using the average isotopic ratios of 18 macroalgal species collected seasonally on and around artificial reefs, since no robust data on the relative abundance of each species is available. For pelagic primary production, most studies so far considered the isotopic ratios of the heterogenous particulate OM pool. Since previous results disentangled the local heterogeneity of this pool (Gregori et al., 2001; Cresson et al., 2012; Bănaru et al., 2014), the isotopic ratios of its two main components, nanophytoplankton ( 2 to $20 \mu \mathrm{m}$ cells) and microphytoplankton ( $>20 \mu \mathrm{m}$ cells), were collected from the literature (Rau et al., 1990; Darnaude et al., 2004). Determination of phytoplankton isotopic ratios is a complex task that requires specific environmental conditions or complex methodologies (Hansman and Sessions, 2015; Miller and Page, 2012). Since the present study was part of a larger project, this would have represented a greater amount of work than could be undertaken. Marine POM sampled in subsurface at the SOMLIT station (Fig.1) was considered as a proxy of microphytoplankton, as it was sampled at a deep (60 m depth) offshore station, where influences of benthic primary production and terrigeneous inputs are negligible, and where $\mathrm{C} / \mathrm{N}$ and $\mathrm{POC} / \mathrm{Chl} a$ ratios are consistent with the predominance of microphytoplankton in the POM (Cresson et al., 2012). Details of the methodology used for nanophytoplankton collection can be found in Rau et al. 
(1990). Briefly, large volumes (140 L) of marine water were filtered on sieves of decreasing porosity (from 150 to $<3 \mu \mathrm{m}$ ). The fraction $<3 \mu \mathrm{m}$ was then resuspended and filtered on $\mathrm{GF} / \mathrm{F}$ filters, before drying and isotopic analyses. To our knowledge, this study is the only one determining isotopic ratios for this phytoplankton size class in the French Mediterranean. Finally, terrigenous influences were assessed by determining the average isotopic ratios of the suspended OM discharged in the sea by the Huveaune River, a coastal river flowing into the sea, during flash flooding events. All four flooding events that occurred during the studied period were sampled. Riverine OM was filtered on precombusted GF/F filters. Filters were acidified for $\delta^{13} \mathrm{C}$ analyses and untreated for $\delta^{15} \mathrm{~N}$ analyses. The actual sampling protocol and values can be found in Cresson et al. $(2012,2014)$.

Stable isotope ratios of suspension-feeders and OM sources were obtained with a continuous flow mass spectrometer (Delta V Advantage, Thermo Scientific). Results are expressed with the classical $\delta$ notation $\delta X=\left(\frac{R_{\text {sample }}}{R_{\text {standard }}}-1\right) \times 10^{3}$, where $\mathrm{X}$ is ${ }^{13} \mathrm{C}$ or ${ }^{15} \mathrm{~N}$ and $\mathrm{R}$ the isotopic ratio ${ }^{13} \mathrm{C} /{ }^{12} \mathrm{C}$ or ${ }^{15} \mathrm{~N} /{ }^{14} \mathrm{~N}$, respectively). Standards were V-PDB for carbon and atmospheric $\mathrm{N}_{2}$ for nitrogen. Measurement precision was calculated from replicated measurements of acetanilide laboratory standard and is $<0.1 \%$. Seasonal, spatial and interspecific differences of isotopic ratios were tested by ANOVA mean comparison tests. Species were gathered in groups of similar isotopic ratios by a clustering analysis, using Euclidean distance and Ward criterion. Numerical analyses were run with R software, using "cluster" packages (Maechler et al., 2013; R Core Team, 2014)

The potential contribution of each OM source to filter-feeders issued from clustering analysis and its seasonal variation was assessed with a Bayesian mixing model, using the SIAR (Stable Isotope Analyses in R) package (Parnell et al., 2010), and considering the 4 OM sources previously cited (Table 2). The choice of an accurate Trophic Enrichment Factor (hereafter TEF) is crucial to the design of the mixing models, as incorrect values can significantly bias the outputs of the model (Bond and Diamond, 2011; Phillips et al., 2014). Assessing accurate TEF is currently one of the key questions in isotopic ecology (Caut et al., 2009; Perga and Grey, 2010; Blanchet-Aurigny et al., 2012). Numerous factors (taxonomy, metabolism, sex, reproduction status, trophic position, nutritional quality of the diet, etc.) can affect the TEF, precluding the use of generalized values, but calling for the use of specifically determined values. Unfortunately, few experimental studies have specifically investigated TEF for suspension-feeders, and for bivalves only (Yokoyama et al., 2005a, 2008; Dubois et al., 2007a). In most studies applying mixing models to suspension-feeders, the TEF used were rather classical and close to the theoretical $1 \%$ - $3 \%$ values (Riera et al., 2004; Gao et al., 2006; Dubois et al., 2007a). The TEF values used in the present study $\left(\Delta \delta^{13} \mathrm{C}=1.28 \pm 0.72, \Delta \delta^{15} \mathrm{~N}=3.25 \pm 0.67\right)$ were calculated as the average of the values used in the studies previously cited. The trophic level of the 
organism i was calculated with the following: $T L_{i}=\frac{\delta^{15} N_{i}-\delta^{15} N_{T B}}{\Delta \delta^{15} N}+1$, with $\delta^{15} \mathrm{~N}_{\mathrm{TB}}$ the $\delta^{15} \mathrm{~N}$ ratio of nanophytoplankton $\left(\delta^{15} \mathrm{~N}=1.77\right)$, considered as the trophic baseline

Since the isotopic ratios of an organism represent integrated information on its diet, this technique provides a convenient tool to determine the realized trophic niche of a community. Several metrics based on isotopic ratios have recently been proposed to describe it (Bearhop et al., 2004; Layman et al., 2007; Newsome et al., 2007; Jackson et al., 2011; Layman et al., 2012; Brind'Amour and Dubois, 2013; Rigolet et al., 2015). In the present study, the interspecific and seasonal variations of the trophic niche were assessed using the $\delta^{13} \mathrm{C}$ range (i.e. the difference between maximum and minimum $\delta^{13} \mathrm{C}$ value) as a proxy of the change in food source use (Layman et al., 2007). The area occupied by organisms in the isotopic space was estimated with TA and SEAb. Total Area (TA, the area of the convex hull encompassing all the points in the $\delta^{13} \mathrm{C}-\delta^{15} \mathrm{~N}$ biplot, Layman et al. 2007) provides information regarding the whole trophic niche occupied by the population but is dependent upon the sample size, whereas the Bayesian estimator of the Standard Ellipse Area (SEAb, Jackson et al., 2011) is a proxy of the averaged isotopic niche corrected for sample size. Finally, trophic diversity and redundancy were assessed by calculating the mean distance to centroid $(C D$, the average Euclidean distance between each individual and the centroid of the group, a proxy of the trophic diversity) and the mean nearest neighbor distance (MNND, the mean of the Euclidean distances between each individual and its nearest neighbor, as a proxy of the trophic redundancy).

\section{Results}

Suspension-feeders exhibited similar isotopic ratios (Fig. 2, Table 1), since differences between minimum and maximum values were 2 \% for $\delta^{13} \mathrm{C}$ (between $-22.65 \pm 0.44 \%$ for Limaria hians and $20.48 \pm 0.75 \%$ for Hiatella artica) and for $\delta^{15} \mathrm{~N}$ (between $3.57 \pm 0.68 \%$ or for Ostrea edulis and $5.69 \pm$ $0.61 \%$ for Phallusia mamillata). Clustering analysis separated two major groups (Fig. S1) with significantly different isotopic ratios (Table 2). The first included ascidians and two bivalve species (Mymachlamis varia and H. artica, hereafter referred to as the "bivalves 2" group). Ascidians and bivalves 2 separated themselves within two distinct sub-clusters. The second cluster grouped all other bivalves (hereafter referred to as the "bivalves 1" group) with the annelid Chaetopterus variopedatus. C. variopedatus will be considered in a separate group, based on both isotopic and taxonomic differences. Carbon isotopic ratios only separated bivalves 2 from the other species, whereas $\delta^{15} \mathrm{~N}$ was most discriminating, with $C$. variopedatus and bivalves 1 group exhibiting the lowest mean values in summer and winter respectively, bivalves 2 group intermediate mean values and ascidians the highest values (Table 1). These differences resulted into differences in trophic levels with the lowest values for $C$. variopedatus and bivalves 1 group, and the highest for ascidians. 
Trophic levels were generally low, ranging between 1.5 and 2.3. Regarding temporal variation, $\delta^{13} \mathrm{C}$ values were significantly higher in winter than in summer, whatever the group. No other spatiotemporal variations were detected (Table 3). Therefore, individuals from both reefs were considered together in the subsequent analyses.

The mixing model was applied separately to the groups resulting from the clustering analysis (Fig. 3, Table S1). Results demonstrated a strong contribution of the pelagic primary production, with a predominance of nanophytoplankton. This contribution was higher in summer for ascidians and the two groups of bivalves. Benthic primary production was not a significant OM source except for the bivalves 2 group in winter. Similarly, isotopic ratios measured for all groups except ascidians and C. variopedatus in summer were consistent with no contribution of terrigenous $\mathrm{OM}$ to the diet of these individuals (i.e. lower limit of the $95 \%$ Bayesian credibility interval $=0$ and higher limit $<15 \%$ ). Regarding $C$. variopedatus, all sources seemed to be potential contributors but the wide range of contributions mostly denoted that the resolution of the current model might not be sufficient and that potential sources might be lacking.

Interspecific and seasonal differences in isotopic niches were also detected. For ascidians, bivalves 2 and $C$. variopedatus, isotopic niche was higher in summer than in winter, notably due to a higher $\delta^{13} \mathrm{C}$ range in this season (Fig. 4). Ascidians displayed the highest $\delta^{13} \mathrm{C}$ range, with a markedly high value $\left(5.48 \%\right.$ ) in summer. In contrast, bivalves 1 displayed the opposite pattern, with lowest $\delta^{13} \mathrm{C}$ range and SEAb values in summer. The trophic diversity (CD) and redundancy (MNND) proxies separated two patterns (Fig. 5). For ascidians and C. variopedatus, values for both indices were lower in winter. For bivalves, indices were higher in winter, with a marked increase for bivalves 2 . The seasonal changes for all indices are summarized in Table 4

\section{Discussion}

Suspension-feeders are the predominant species in the vast majority of benthic habitats. The coexistence of several syntopic suspension-feeding species at a small-spatial scale and the potential trophic competition between cultured and wild suspension-feeders have generated a large body of work regarding trophic competition in highly productive environments, where benthic, pelagic and terrestrial OM sources were abundant. Is this trend conserved in an oligotrophic environment?

\subsection{What OM source fuels which suspension-feeder?}

In the present study, the use of stable isotope ratios to track the origin of the OM fueling the suspension feeders appeared appropriate, since few OM sources (i.e. the most relevant to the system) with well discriminated isotopic ratios were considered. This enabled identification of 
nanophytoplankton as the main OM source fueling the system. Nanophytoplankton is the main component of the pelagic ecosystem in the bay of Marseille (Gregori et al., 2001; Cresson et al., 2012; Bănaru et al., 2014) as well as in other coastal zones in the Mediterranean (Coma and Ribes, 2003; Garrido et al., 2014). On the basis of the analysis of the morphology of the filtration and retention systems (Ward and Shumway, 2004; Riisgård and Larsen, 2010) and on experimental filtration studies, nanophytoplankton was demonstrated as the main food source for ascidians (Ribes et al., 1998; Coma and Ribes, 2003; Kang et al., 2009; Lesser and Slattery, 2015; Lacoste et al., in press) and as potentially important for suspension-feeding annelids (Jordana et al., 2001). The smallest size-classes of phytoplankton were also identified as the main OM source for other suspension-feeding groups, mainly sponges or octocorals in the Mediterranean (Topçu et al., 2010) or in other oligotrophic ecosystems (Elias-Piera et al., 2013; Orejas et al., 2003; Ribes et al., 2003; Trussell et al., 2006). Regarding bivalves, studies identified diatoms, whether pelagic or benthic, as the preferred dietary substrates (Riera and Richard, 1996; Dupuy et al., 2000; Riera et al., 2002; Riera, 2007, 2008; Xu and Yang, 2007; Kang et al., 2009; Lefebvre et al., 2009; Pernet et al., 2012). In the artificial reef system studied here, benthic diatoms can be considered as absent due to the depth, and pelagic diatoms were scarce in most seasons (Bănaru et al., 2014). Nevertheless, bivalves can show a high degree of trophic plasticity and retain a large amount of food from other sources, even the smallest ones (Dupuy et al., 2000; Xu and Yang, 2007). In addition, the seasonal variation of the isotopic ratios in suspension-feeders is consistent with the seasonal succession in the pelagic community and the spring bloom of nanophytoplankton already detected in the Bay of Marseille (Gregori et al., 2001; Cresson et al., 2012). Considering an integration time of ca. 2 months in bivalves' tissues (Dubois et al., 2007a), the lower isotopic values in summer would reflect the integration of the predominant production during the spring bloom. Suspension feeding is considered as an optimized feeding mechanism minimizing energy costs (Riisgård and Larsen, 2010). Even if the smallest phytoplanktonic cells might represent a lower gross amount of carbon (Dupuy et al., 2000), as denoted by the lower concentration of biochemical compounds in suspension during their bloom (Cresson et al., 2012), the higher cell concentration might allow easier retention for a lower energy cost (Kach and Ward, 2008) and thus optimize the feeding efficiency. In winter, nanophytoplankton is still observed in the water column but in lower quantities (Gregori et al., 2001). It is thus unsurprising that its contribution decreases for all groups.

The other surprising trend is the rather low trophic position calculated for all organisms. In the present study, calculation of trophic levels based on $\delta^{15} \mathrm{~N}$ values ranged between 1.5 and 2.2, which is lower than the trophic levels of 2 or 3 expected and observed for suspension feeders (Colombo et al., 2013; Richoux et al., 2014). The use of an inappropriate TEF value may be considered, since the 
direct application of laboratory-derived values to natural individuals has been questioned (Yokoyama et al., 2008). The bias might be stronger for ascidians and $C$. variopedatus, since the TEF values result from bivalve-derived studies. A predominant integration of bacterial-derived OM could be another explanation for these rather low values. Diazotrophic bacteria have $\delta^{15} \mathrm{~N}$ ratios close to $0 \%$ or even negative (Karlson et al., 2014; Briand et al., 2015) and are predominant in two terrigenous water inputs in the bay of Marseille (Huveaune River and wastewater outfall), with the low isotopic ratios of the wastewater outfall consistent with the predominance of diazotrophic bacteria (Bănaru et al., 2014). They are also abundant during summer blooms in the bay of Marseille ( 2 to $510^{2}$ cells $\mathrm{mL}^{-1}$, Le Moal and Biegala, 2009; $710^{4}$ events $\mathrm{mL}^{-1}$ Zhao et al., 2012). With such high abundance, bacteria can form aggregates allowing easier retention by suspension feeders (Kach and Ward, 2008). A significant contribution of diazotrophic bacteria to the diet of suspension feeders might explain the unexpectedly low $\delta^{15} \mathrm{~N}$ and trophic levels measured in the Bay of Marseille. Considering bacteria as a food source might also explain why the lowest $\delta^{15} \mathrm{~N}$ values were measured for $C$. variopedatus. Its retention-system based on a mucus-net mesh is the most efficient to retain particles as small as 0.5 um (Flood and Fiala-Médioni, 1982; Riisgård and Larsen, 2010; Jumars et al., 2015). Bacteria might represent the missing end-member to complete the mixing-model for this species and are considered as a potential food source for bivalves (Xu and Yang, 2007; Kharlamenko et al., 2008; Pernet et al., 2012; Karlson et al., 2014) and for ascidians (Lesser and Slattery, 2015; Ribes et al., 1998). It could also explain the generalized pattern of low $\delta^{15} \mathrm{~N}$ values recorded in the Bay of Marseille, notably for zooplankton (Bănaru et al., 2014; Espinasse et al., 2014; Tiano et al., 2014). In the Baltic Sea, previous results confirmed that diazotrophic bacteria can be a significant food source for the whole trophic network (zooplankton and benthic invertebrates), since it can represent up to $80 \%$ of the diet of some species (Karlson et al., 2014; Lesutienè et al., 2014). Assessing accurately the contribution of this source to the diet of suspension feeders, for example through their integration as an endmember in a mixing model, is nevertheless complex since it would require an accurate determination of $\delta^{13} \mathrm{C}$ value for diazotrophic bacteria in the bay of Marseille. Other trophic markers, such as fatty acids, can be considered as a useful complementary tool, since their use demonstrated a higher contribution of bacteria to oysters' diet during summer in a Mediterranean lagoon (Pernet et al., 2012).

4.2. Is the suspension-feeder community trophic pattern conserved in oligotrophic ecosystems?

Since $\mathrm{C}$ and $\mathrm{N}$ stable isotope ratios provide information about the organic matter sources integrated by organisms, they have been used as a proxy of ecosystem functioning, as oligotrophy may affect resources availability for consumers. In eutrophic systems, enhanced primary production increases coupling between pelagic and benthic trophic networks, and reduces the isotopic differences 
between suspension feeders and deposit feeders, grazers or predators (Vadeboncoeur et al., 2003; Gaudron et al., 2015). Nevertheless, no study has assessed such a pattern on suspension feeders only. In a eutrophic context where food sources are diverse and available, wide (up to $4 \%$ for $\delta^{13} \mathrm{C}$ ) interspecific differences can be observed, in contrast to to the pattern observed in the present study. Such a difference is classically interpreted as the establishment of resource sharing mechanisms, to limit interspecific trophic competition (Riera et al., 2002; Rossi et al., 2004; Yokoyama et al., 2005b; Dubois et al., 2007b, 2007c; Lefebvre et al., 2009). But similar differences are also observed in zones where chlorophyll a concentrations are lower (Kang et al., 2009; Yakovis et al., 2012; Lacoste et al., in press), meaning that oligotrophy may not be the major factor driving this difference. Species-specific abilities to increase the filtration rate, to reject particle of poor nutritional interest, or conversely, their inability to exert a feeding choice, may mask the effects of oligotrophy. In addition, chlorophyll $a$ or nutrient concentrations were rarely combined with isotope ratios, precluding a firm conclusion on that point (Table S3). Interestingly, all studies except one were performed in coastal shallow zones (Table S3). Isotopic similarity among suspension-feeders was also observed in deep (66-350 m depth) Arctic gorgonians, and was also interpreted as the consumption of the sole food source available outside the phytoplankton blooming period (Elias-Piera et al., 2013). In deep zones, food supply might be even less diverse but not less abundant. In a study comparing dietary patterns in deep (25 $\mathrm{m}$ ) and shallow (12 m depth) sponges, Trussel et al. (2006) demonstrated that picoplankton was more abundant in deep sites, resulting in a more efficient retention and a higher growth rate for deeper sponges. Inferring a similar pattern in the Bay of Marseille's artificial reefs may explain the colonization success of suspension feeders (Rouanet et al., 2015). Another interesting trend commonly observed, is the similarity of the relative trophic positions between species, whatever the location (Dubois and Colombo, 2014). Bivalves display markedly higher values than ascidians, due to the retention of ${ }^{13} \mathrm{C}$-enriched diatoms for bivalves and of nanophytoplankton for ascidians. This pattern is observed in all studies comparing ascidians and bivalves except the present one, confirming that local environmental conditions have a strong effect on bivalve feeding patterns (Grall et al., 2006; Dubois et al., 2007c; Kang et al., 2009; Schaal et al., 2010; Yakovis et al., 2012; Lacoste et al., in press; Tab S3). Suspension-feeding annelids are commonly considered to have the highest trophic position, based on their expected ability to retain zooplankton (Dubois et al., 2007c; Lefebvre et al., 2009; Richoux et al., 2014; Richoux and Ndhlovu, 2014). This trend is not conserved in the present system and could also trace the influence of the low diversity and availability of food resources on the food partitioning.

\subsection{Seasonal variation of isotopic indices as a proxy of species specific abilities}


The different seasonal patterns observed for all groups of suspension-feeders might reflect their interspecific difference in sorting abilities. Previous studies have already demonstrated that speciesspecific retention mechanisms can strongly affect the inter- and intraspecific trophic relationships (Dubois and Colombo, 2014; Richoux and Ndhlovu, 2014). Bivalves are commonly considered as a group with high capability to sort and select or reject food sources (Ward and Shumway, 2004; Richoux and Ndhlovu, 2014; Dubois and Colombo, 2014). They can select particles with higher nutritional value and reject in pseudo-feces the particles of poor nutritional interest (Bracken et al., 2012). In winter, an increase of CD and NND was detected for both bivalve groups. In the face of a decrease of nanophytoplankton concentrations in winter, the CD increase reflected an increase of the trophic diversity, i.e. an increase of the number of sources retained. For the bivalves 1 group, the change was slight and might be explained by the increased retention of microphytoplankton. For the bivalves 2 group, the increase was more pronounced and was largely explained by the use of macroalgal detritus. The absence of laterofrontal cirri in the retention system was demonstrated for pectinid bivalves (such as M. varia), causing a lower retention efficiency for small particles (Ward and Shumway, 2004; Riisgård and Larsen, 2010). M. varia also displayed the highest $\delta^{13} C$ values of all bivalve species in a previous study (Schaal et al., 2010) potentially confirming that the morphological constraint is conserved regardless of the ecosystems. This lower efficiency might also prevent some individuals of the bivalves 2 group from depending exclusively on nanophytoplankton in summer, explaining the opposite seasonal trend for $\delta^{13} \mathrm{C}$ range between the two groups of bivalves and the wide ranges of source contributions in the mixing-model for the bivalves 2 group. Even if the interindividual variation was not specifically investigated in the present study, it was demonstrated to play a significant role, potentially driven by intraspecific variation in morphological structures (Dubois and Colombo, 2014). In addition, using detrital vegetal matter requires specific enzymatic systems (Navarro et al., 2009). It may thus be hypothesized that these species also used nanophytoplankton as the preferred food source when abundant but have their feeding selection constrained by anatomical specificities in winter. Macroalgal detritus can thus represent an interesting food source to complete the diet of those species even if the ratio between energy input and filtration cost is lower for this food source. Finally, the results observed for ascidians and for the polychaete C. variopedatus were consistent with the expected opportunism of these species. Even if nanophytoplankton is their preferred food source, ascidians have the ability to retain all particles from 0.5 to $100 \mu \mathrm{m}$ (Ribes et al., 1998). Similarly, polychaetes are considered to have limited sorting abilities and a wide range of possible food sources (Dubois and Colombo, 2014). Both groups share a similar sieving system, based on the retention of particles on a mucus trap (Flood and Fiala-Médioni, 1982; Jumars et al., 2015; Ribes et al., 1998; Riisgård and Larsen, 2010). The similar isotopic trends observed for both groups (i.e. lower index values in winter, whatever the magnitude of the change) 
support the idea that these species were "the ultimate opportunists" (sensu Coma et al., 2001) in the sense that their trophic behavior is directly coupled with the composition of the suspended OM pool. In summer, the $\delta^{13} \mathrm{C}$ range recorded for ascidians was consistent with the use of a wide range of food sources and without preferential sorting between them. Similarly, CD and NND were high for C. variopedatus, consistently with the maximized use of all food sources available. The seasonal decrease observed in winter for all trophic niche indices was thus consistent with the constrained use of a lower range of available food sources. The contribution of riverine derived OM only to the summer diet of $C$. variopedatus, and to a lesser extent of ascidians, might also demonstrate the influence of their lower sorting abilities. The Huveaune River OM inputs are of poor nutritional quality, as denoted by their high insoluble carbohydrate concentrations and $\mathrm{C} / \mathrm{N}$ ratios, and by the predominance of bacteria (Cresson, 2013; Bănaru et al., 2014). These inputs might be sorted by bivalves but not by ascidians and C. variopedatus. Richoux and Ndhlovu (2014) previously observed a similar decreasing influence of terrigenous inputs based on sorting abilities. The contribution of riverine inputs is higher in the polychaete Gunnarea gaimardi than in the bivalve Perna perna, since the mussel sorting abilities allow discarding riverine inputs of poor nutritional quality. Nevertheless, firm conclusions are precluded for the polychaete since the low sample size might bias some metrics calculations and the TEF might be questioned. More generally, assessing efficiently the trophic ecology of polychaetes on the basis of their stable isotope ratios was demonstrated to be a complex task (Richoux and Ndhlovu, 2014), possibly due to the wide range of feeding mechanisms in use in this taxon (Jumars et al., 2015).

Analyzing the trophic ecology of co-occurring suspension-feeders has been the core of numerous studies but the effect of depth and oligotrophy has been poorly documented. The present study demonstrated that lower food diversity and availability clearly limits the interspecific partitioning of resources. This lower diversity also constrained the sorting between food resources, even if the mechanisms observed elsewhere seemed to be conserved in the present study. The high trophic plasticity and opportunism of suspension-feeders was also confirmed, since benthic and pelagic food sources can contribute to their diet, and since suspension-feeders were able to switch their diet to cope with resource scarcity. Unexpectedly, diazotrophic bacteria can be considered as a significant food source in the bay of Marseille, originating in the low $\delta^{15} \mathrm{~N}$ and trophic level values. The present results demonstrated that a firm conclusion regarding resource sharing mechanisms in suspension feeders cannot be only based on results from eutrophic environments, and that further studies in other ecological contexts are needed before considering a general pattern.

\section{Acknowledgements}


This work was performed during P. Cresson's PhD and is part of the RECIFS PRADO scientific survey, funded by grants from the city of Marseille and from the "Agence de l'Eau Rhône Mediterranée Corse". This work benefited from the help of our colleagues to whom we are grateful, for their assistance during field work and analyses and for numerous exchanges and constructive discussions: M. F. Fontaine, M. Ourgaud, M. Perret-Boudouresque, F. Morat, B. De Ligondes, F. Zuberer, G. Bleton, C.F. Boudouresque, M. Verlaque (Aix-Marseille Université, OSU Pytheas), L. Le Diréach, E. Rouanet, P. Astruch, (GIS Posidonie). Isotopic analyses were performed by P. Richard and G. Guillou (LIENSs laboratory, Université de La Rochelle). A. Goujard (GIS Posidonie) designed the map figure 1. We would like to thank all authors who responded positively to our requests for unpublished data: E.L. Yakovis, S.F. Dubois, S. Lefebvre, V. Kharlamenko, V. Costa and G. Schall. We also thank Michael Paul for improvement of the English text and two anonymous reviewers for their highly valuable suggestions that helped us to improve this manuscript. Symbols in the graphical abstract are used courtesy of the Integration and Application Network, University of Maryland Center for Environmental Science (ian.umces.edu/symbols/).

\section{Bibliographical references}

Bănaru, D., Carlotti, F., Barani, A., Grégori, G., Neffati, N., Harmelin-Vivien, M., 2014. Seasonal variation of stable isotope ratios of size-fractionated zooplankton in the Bay of Marseille (NW Mediterranean Sea). J. Plankton Res. 36, 145-156.

Bearhop, S., Adams, C.E., Waldron, S., Fuller, R.A., MacLeod, H., 2004. Determining trophic niche width: a novel approach using stable isotope analysis. J. Anim. Ecol. 73, 1007-1012. doi:10.1111/j.0021-8790.2004.00861.x

Blanchet-Aurigny, A., Guillou, M., Pernet, F., Gaffet, J.D., Dubois, S.., 2012. Tissue-diet discrimination factors of isotopic ratios $\left(\Delta \delta^{13} \mathrm{C}\right.$ and $\Delta \delta^{15} \mathrm{~N}$ ) in two brittlestar species: Effect of reproductive state, diet and tissue composition. J. Exp. Mar. Biol. Ecol. 426-427, 68-77.

Bode, A., Alvarez-Ossorio, M.T., Varela, M., 2006. Phytoplankton and macrophyte contributions to littoral food webs in the Galician upwelling estimated from stable isotopes. Mar. Ecol.-Prog. Ser. 318, 89-102.

Bond, A.L., Diamond, A.., 2011. Recent Bayesian stable-isotope mixing models are highly sensitive to variations in discrimination factors. Ecol. Appl. 21, 1017-1023.

Bracken, M., Menge, B., Foley, M., Sorte, C., Lubchenco, J., Schiel, D., 2012. Mussel selectivity for high-quality food drives carbon inputs into open-coast intertidal ecosystems. Mar. Ecol.-Prog. Ser. 459, 53-62. doi:10.3354/meps09764

Briand, M., Bonnet, X., Goiran, C., Guillou, G., Letourneur, Y., 2015. Major Sources of Organic Matter in a Complex Coral Reef Lagoon: Identification from Isotopic Signatures $\left(\delta^{13} \mathrm{C}\right.$ and $\left.\delta^{15} \mathrm{~N}\right)$. PLOS ONE 10. doi:doi:10.1371/journal.pone.0131555

Brind'Amour, A., Dubois, S.F., 2013. Isotopic diversity indices: how sensitive to food web structure? PloS One 8, e84198.

Buss, L.W., Jackson, J.B.C., 1981. Planktonic food availability and suspension-feeder abundance: Evidence of in situ depletion. J. Exp. Mar. Biol. Ecol. 49, 151-161. doi:10.1016/00220981(81)90067-8

Caut, S., Angulo, E., Courchamp, F., 2009. Variation in discrimination factors $\left(\Delta^{15} \mathrm{~N}\right.$ and $\left.\Delta^{13} \mathrm{C}\right)$ : the effect of diet isotopic values and applications for diet reconstruction. J. Appl. Ecol. 46, 443453. doi:10.1111/j.1365-2664.2009.01620.x

Charbonnel, E., Harmelin, J.G., Carnus, F., Le Direac'h, L., Ruitton, S., Lenfant, P., Beurois, J., 2011. Artificial reefs in Marseille (France, Mediterranean Sea): From complex natural habitat to concept of efficient artificial reef design. Braz. J. Oceanogr. 59, 177-178.

Cheung, S.G., Wai, H.Y., Shin, P.K., 2010. Fatty acid profiles of benthic environment associated with artificial reefs in subtropical Hong Kong. Mar. Pollut. Bull. 60, 303-308. 
Colombo, F., Costa, V., Dubois, S.F., Gianguzza, P., Mazzola, A., Vizzini, S., 2013. Trophic structure of vermetid reef community: High trophic diversity at small spatial scales. J. Sea Res. 77, 93-99.

Coma, R., Ribes, M., 2003. Seasonal Energetic Constraints in Mediterranean Benthic Suspension Feeders: Effects at Different Levels of Ecological Organization. Oikos 101, 205-215. doi: $10.2307 / 3548359$

Coma, R., Ribes, M., Gili, J.-M., Hughes, R.N., 2001. The ultimate opportunists: consumers of seston. Mar. Ecol.-Prog. Ser. 219, 305-308. doi:10.3354/meps219305

Connell, J.H., 1961. The influence of interspecific competition and other factors on the distribution of the barnacle Chthamalus stellatus. Ecology 42, 710-723.

Côté, J., Himmelman, J.H., Claereboudt, M.R., 1994. Separating effects of limited food and space on growth of the giant scallop Placopecten magellanicus in suspended culture. Mar. Ecol. Prog. Ser. 106, 85-91.

Cresson, P., 2013. Fonctionnement trophique des récifs artificiels de la baie du Prado (Marseille, France): origine et devenir de la matière organique (PhD thesis). Aix-Marseille Université, Marseille, France.

Cresson, P., Ruitton, S., Fontaine, M.-F., Harmelin-Vivien, M., 2012. Spatio-temporal variation of suspended and sedimentary organic matter quality in the Bay of Marseilles (NW Mediterranean) assessed by biochemical and isotopic analyses. Mar. Pollut. Bull. 64, 11121121. doi:10.1016/j.marpolbul.2012.04.003

Cresson, P., Ruitton, S., Harmelin-Vivien, M., 2014. Artificial reefs do increase secondary biomass production: mechanisms evidenced by stable isotopes. Mar. Ecol. Prog. Ser. 509, 15-26. doi:10.3354/meps.10866

Darnaude, A., Salen-Picard, C., Polunin, N.V.C., Harmelin-Vivien, M., 2004. Trophodynamic linkage between river runoff and coastal fishery yield elucidated by stable isotope data in the Gulf of Lions (NW Mediterranean). Oecologia 138, 325-332.

Decottignies, P., Beninger, P.G., Rincé, Y., Riera, P., 2007. Trophic interactions between two introduced suspension-feeders, Crepidula fornicata and Crassostrea gigas, are influenced by seasonal effects and qualitative selection capacity. J. Exp. Mar. Biol. Ecol. 342, 231-241. doi:10.1016/j.jembe.2006.10.005

De Montaudoin, X., Audemard, C., Labourd, P.-J., 1999. Does the slipper limpet (Crepidula fornicata L.) impair oyster growth and zoobenthos biodiversity? A revisited hypothesis. J. Exp. Mar. Biol. Ecol. 235, 105-124.

Dubois, S., Blin, J.-L., Bouchaud, B., Lefebvre, S., 2007a. Isotope trophic-step fractionation of suspension-feeding species: implications for food partitioning in coastal ecosystems. J. Exp. Mar. Biol. Ecol. 351, 121-128.

Dubois, S.F., Colombo, F., 2014. How picky can you be? Temporal variations in trophic niches of cooccurring suspension-feeding species. Food Webs 1, 1-9. doi:10.1016/j.fooweb.2014.07.001

Dubois, S., Marin-Léal, J.C., Ropert, M., Lefebvre, S., 2007b. Effects of oyster farming on macrofaunal assemblages associated with Lanice conchilega tubeworm populations: A trophic analysis using natural stable isotopes. Aquaculture 271, 336-349.

Dubois, S., Orvain, F., Marin Leal, J.C., Ropert, M., Lefebvre, S., 2007c. Small-scale spatial variability of food partitioning between cultivated oysters and associated suspension-feeding species, as revealed by stable isotopes. Mar. Ecol. Prog. Ser. 336, 151-160.

Dupuy, C., Vaquer, A., Lam-Höai, T., Rougier, C., Mazouni, N., Lautier, J., Collos, Y., le Gall, S., 2000. Feeding rate of the oyster Crassostrea gigas in a natural planktonic community of the Mediterranean Thau Lagoon. Mar. Ecol.-Prog. Ser. 205, 171-184. doi:10.3354/meps205171

Elias-Piera, F., Rossi, S., Gili, J.M., Orejas, C., 2013. Trophic ecology of seven Antarctic gorgonian species. Mar. Ecol. Prog. Ser. 477, 93-106.

Espinasse, B., Harmelin-Vivien, M., Tiano, M., Guilloux, L., Carlotti, F., 2014. Patterns of variations in C and $\mathrm{N}$ stable isotope ratios in size-fractionated zooplankton in the Gulf of Lion, NW Mediterranean Sea. J. Plankton Res. 36, 1204-1215. 
Flood, T., Fiala-Médioni, A., 1982. Structure of the mucous feeding filter of Chaetopterus variopedatus (Polychaeta). Mar. Biol. 72, 27-33.

Gao, Q.-F., Shin, P.K.., Lin, G.-H., Chen, S.H., Cheung, S.., 2006. Stable isotope and fatty acid evidence for uptake of organic waste by green-lipped mussels Perna viridis in a polyculture fish farm system. Mar. Ecol.-Prog. Ser. 317, 273-283.

Garrido, M., Koeck, B., Goffart, A., Collignon, A., Hecq, J.-H., Agostini, S., Marchand, B., Lejeune, P., Pasqualini, V., 2014. Contrasting Patterns of Phytoplankton Assemblages in Two Coastal Ecosystems in Relation to Environmental Factors (Corsica, NW Mediterranean Sea). Diversity 6, 296-322.

Gaudron, S.M., Grangeré, K., Lefebvre, S., 2015. The Comparison of $\delta^{13} \mathrm{C}$ Values of a Deposit-and a Suspension-Feeder Bio-Indicates Benthic vs. Pelagic Couplings and Trophic Status in Contrasted Coastal Ecosystems. Estuaries Coasts 1-11.

Gili, J.-M., Coma, R., 1998. Benthic suspension feeders: their paramount role in littoral marine food webs. Trends Ecol. Evol. 13, 316-321.

Grall, J., Le Loc'h, F., Guyonnet, B., Riera, P., 2006. Community structure and food web based on stable isotopes $\left(\delta^{15} \mathrm{~N}\right.$ and $\left.\delta^{13} \mathrm{C}\right)$ analysis of a North Eastern Atlantic maerl bed. J. Exp. Mar. Biol. Ecol. 338, 1-15. doi:10.1016/j.jembe.2006.06.013

Gregori, G., Colosimo, A., Denis, M., 2001. Phytoplankton group dynamics in the Bay of Marseilles during a 2-year survey based on analytical flow cytometry. Cytometry 44, 247-256.

Gutt, J., 2006. Coexistence of macro-zoobenthic species on the Antarctic shelf: an attempt to link ecological theory and results. Deep Sea Res. II 53, 1009-1028.

Hansman, R.L., Sessions, A.L., 2015. Measuring the in situ carbon isotopic composition of distinct marine plankton populations sorted by flow cytometry. Limnol. Oceanogr. Methods n/a-n/a. doi:10.1002/lom3.10073

Jackson, A.L., Inger, R., Parnell, A.C., Bearhop, S., 2011. Comparing isotopic niche widths among and within communities: SIBER - Stable Isotope Bayesian Ellipses in R. J. Anim. Ecol. 80, 595-602. doi:10.1111/j.1365-2656.2011.01806.x

Jordana, E., Grémare, A., Lantoine, F., Courties, C., Charles, F., Amouroux, J.M., Vétion, G., 2001. Seasonal changes in the grazing of coastal picoplankton by the suspension-feeding polychaete Ditrupa arietina (O.F. Müller). J. Sea Res. 46, 245-259. doi:10.1016/S13851101(01)00082-X

Jumars, P.A., Dorgan, K.M., Lindsay, S.M., 2015. Diet of Worms Emended: An Update of Polychaete Feeding Guilds. Annu. Rev. Mar. Sci. 7, 497-520. doi:10.1146/annurev-marine-010814020007

Kach, D.J., Ward, J.E., 2008. The role of marine aggregates in the ingestion of picoplankton-size particles by suspension-feeding molluscs. Mar. Biol. 153, 797-805.

Kang, C.-K., Choy, E.J., Hur, Y.-B., Myeong, J.-I., 2009. Isotopic evidence of particle size dependent food partitioning in cocultured seasquirt Halocyntia roretzi and Pacific oyster Crassostrea gigas. Aquat. Biol. 6, 289-302.

Karlson, A.M.L., Gorokhova, E., Elmgren, R., 2014. Nitrogen Fixed By Cyanobacteria Is Utilized By Deposit-Feeders. PLoS ONE 9, e104460. doi:10.1371/journal.pone.0104460

Kharlamenko, V., Kiyashko, S., Rodkina, S., Imbs, A., 2008. Determination of food sources of marine invertebrates from a subtidal sand community using analyses of fatty acids and stable isotopes. Russ. J. Mar. Biol. 34, 101-109.

Lacoste, E., Raimbault, P., Harmelin-Vivien, M., Gaertner-Mazouni, N., in press. Trophic relationships between the farmed pearl oyster Pinctada margaritifera and its epibionts revealed by stable isotopes and feeding experiments. Aquac. Environ. Interact. doi:doi: 10.3354/aei00157

Layman, C.A., Araujo, M.S., Boucek, R., Hammerschlag-Peyer, C.M., Harrison, E., Jud, Z.R., Matich, P., Rosenblatt, A.E., Vaudo, J.J., Yeager, L.A., Post, D.M., Bearhop, S., 2012. Applying stable isotopes to examine food-web structure: an overview of analytical tools. Biol. Rev. 87, 545562. doi:10.1111/j.1469-185X.2011.00208.x 
Layman, C.., Arrington, D.A., Montaña, C.G., Post, D.M., 2007. Can stable isotopes ratios provide for community-wide measures of trophic structure. Ecology 88, 42-48.

Lefebvre, S., Marìn Leal, J.C., Dubois, S., Orvain, F., Blin, J.-L., Bataillé, M.-P., Ourry, A., Galois, R., 2009. Seasonal dynamics of trophic relationships among co-occuring suspension-feeders in two sellfish culture dominated ecosystems. Estuar. Coast. Shelf Sci. 82, 415-425.

Le Moal, M., Biegala, I.C., 2009. Diazotrophic unicellular cyanobacteria in the northwestern Mediterranean Sea: A seasonal cycle. Limnol. Oceanogr. 54, 844-855.

Lesser, M.P., Shumway, S.E., Cucci, T., Smith, J., 1992. Impact of fouling organisms on mussel rope culture: interspecific competition for food among suspension-feeding invertebrates. J. Exp. Mar. Biol. Ecol. 165, 91-102.

Lesser, M., Slattery, M., 2015. Picoplankton consumption supports the ascidian Cnemidocarpa verrucosa in McMurdo Sound, Antarctica. Mar. Ecol. Prog. Ser. 525, 117-126.

Lesutienè, J., Bukaveckas, P.A., Gasiūnaitè, Z.R., Pilkaitytè, R., Razinkovas-Baziukas, A., 2014. Tracing the isotopic signal of a cyanobacteria bloom through the food web of a Baltic Sea coastal lagoon. Estuar. Coast. Shelf Sci. 138, 47-56. doi:10.1016/j.ecss.2013.12.017

Maechler, M., Rousseeuw, P., Struyf, A., Hubert, M., Kornick, K., 2013. cluster. Cluster Analysis Basics and Extension. $R$ package version 1.14.4.

Marín Leal, J.C., Dubois, S., Orvain, F., Galois, R., Blin, J.-L., Ropert, M., Bataillé, M.-P., Ourry, A., Lefebvre, S., 2008. Stable isotopes $\left(\delta^{13} \mathrm{C}, \delta^{15} \mathrm{~N}\right)$ and modelling as tools to estimate the trophic ecology of cultivated oysters in two contrasting environments. Mar. Biol. 153, 673-688. doi:10.1007/s00227-007-0841-7

Miller, M.W., 2002. Using ecological processes to advance artificial reef goals. ICES J. Mar. Sci. 59, 2731.

Miller, R.J., Page, H.M., 2012. Kelp as a trophic resource for marine suspension feeders: a review of isotope-based evidence. Mar. Biol. 159, 1391-1402.

Navarro, E., Méndez, S., Ibarrola, I., Urrutia, M.B., 2009. Comparative utilization of phytoplankton and vascular plants detritus by the cockle Cerastoderma edule: digestive response during diet acclimatation. Aquat. Biol. 6, 247-262.

Newsome, S.., Martínez del Rio, C., Bearhop, S., Phillips, D.L., 2007. A niche for trophic ecology. Front. Ecol. Environ. 5, 429-436.

Orejas, C., Gili, J.-M., Arntz, W., 2003. The role of the small planktonic communities in the diet of two Antarctic octocorals (Primnoisis antarctica and Primnoella sp.). Mar. Ecol. Prog. Ser. 250, 105-116.

Parnell, A.C., Inger, R., Bearhop, S., Jackson, A.L., 2010. Source partitioning using stable isotopes: Coping with too much variation. Plos One 5, e9672. doi:10.1371/journal.pone.0009672

Perga, M.-E., Grey, J., 2010. Laboratory measures of isotope discrimination factors: comments on Caut, Angulo \& Courchamp (2008, 2009). J. Appl. Ecol. 47, 942-947. doi:10.1111/j.13652664.2009.01730.x

Pernet, F., Malet, N., Pastoureaud, A., Vaquer, A., Quéré, C., Dubroca, L., 2012. Marine diatoms sustain growth of bivalves in a Mediterranean lagoon. J. Sea Res. 68, 20-32.

Petersen, J.K., 2007. Ascidian suspension feeding. J. Exp. Mar. Biol. Ecol. 342, 127-137.

Phillips, D.L., Inger, R., Bearhop, S., Jackson, A.L., Moore, J.W., Parnell, A.C., Semmens, B.X., Ward, E.J., 2014. Best practices for use of stable isotope mixing models in food-web studies. Can. J. Zool. 92, 823-835. doi:10.1139/cjz-2014-0127

Rau, G.H., Teyssie, J.L., Rassoulzadegan, F., Fowler, S.W., $1990 .{ }^{13} \mathrm{C} /{ }^{12} \mathrm{C}$ and ${ }^{15} \mathrm{~N} /{ }^{14} \mathrm{~N}$ variations among size-fractionated marine particles: implications for their origin and trophic relationships. Mar. Ecol.-Prog. Ser. 59, 33-38.

$R$ Core Team, 2014. $R$ : A language and environment for statistical computing. $R$ foundation for Statistical computing, Vienna, Austria.

Ribes, M., Coma, R., 2005. The role of engineer species in the benthic-pelagic coupling: the study case of a Mediterranean gorgonian. Limnol. Oceanogr. Summer Meet. 128. 
Ribes, M., Coma, R., Atkinson, M.J., Kinzie III, R.A., 2003. Particle removal by coral reef community: picoplankton is a major source of nitrogen. Mar. Ecol.-Prog. Ser. 257, 13-23.

Ribes, M., Coma, R., Gili, J.-M., 1998. Seasonal variation of in-situ feeding rates by the temperate ascidian Halocyntia papillosa. Mar. Ecol.-Prog. Ser. 175, 201-213.

Richoux, N.B., Ndhlovu, R.T., 2014. Temporal variability in the isotopic niches of rocky shore grazers and suspension-feeders. Mar. Ecol. doi:10.1111/maec.12200

Richoux, N., Vermeulen, I., Froneman, P.W., 2014. Stable isotope ratios indicate differential omnivory among syntopic rocky shore suspension-feeders. Mar. Biol. 161, 971-984. doi:10.1007/s00227-013-2358-6

Riera, P., 2007. Trophic subsidies of Crassostrea gigas, Mytilus edulis and Crepidula fornicata in the Bay of Mont Saint Michel (France): $A \delta^{13} \mathrm{C}$ and $\delta^{15} \mathrm{~N}$ investigation. Estuar. Coast. Shelf Sci. 72, 33-41.

Riera, P., 2008. Trophic plasticity in similar habitats: an example which severely limits generalization among ecosystems. JMBA2 - Biodivers. Rec. 1-3.

Riera, P., Richard, P., 1996. Isotopic determination of food sources of Crassostrea gigas along a trophic gradient in the estuarine bay of Marennes-Oléron. Estuar. Coast. Shelf Sci. 42, 347360.

Riera, P., Stal, L.J., Nieuwenhuize, J., 2002. $\delta^{13} \mathrm{C}$ versus $\delta^{15} \mathrm{~N}$ study of co-occurring molluscs within a community dominated by Crassostrea gigas and Crepidula fornicata (Oosterschelde, The Netherlands). Mar. Ecol.-Prog. Ser. 240, 291-295. doi:10.3354/meps240291

Riera, P., Stal, L., Nieuwenhuize, J., 2004. Utilization of food sources by invertebrates in a man-made intertidal ecosystem (Westerschelde, the Netherlands): a $\delta^{13} \mathrm{C}$ and $\delta^{15} \mathrm{~N}$ study. J. Mar. Biol. Assoc. U. K. 84, 323-326.

Rigolet, C., Thiébaut, E., Brind'Amour, A., Dubois, S.F., 2015. Investigating isotopic functional indices to reveal changes in the structure and functioning of benthic communities. Funct. Ecol. doi:10.1111/1365-2435.12444

Riisgård, H., Larsen, P., 2010. Particle capture mechanisms in suspension-feeding invertebrates. Mar. Ecol.-Prog. Ser. 418, 255-293. doi:10.3354/meps08755

Rossi, F., Herman, P., Middelburg, J., 2004. Interspecific and intraspecific variation of $\delta \mathrm{C}$ and $\delta \mathrm{N}$ in deposit-and suspension-feeding bivalves (Macoma balthica and Cerastoderma edule): Evidence of ontogenetic changes in feeding mode of Macoma balthica. Limnol. Oceanogr. 49, 408-414.

Rouanet, E., Astruch, P., Antonioli, A., Bonhomme, P., Fourt, M., Bonhomme, D., Goujard, A., Le Diréach, L., Perez, T., 2015. How artificial reefs design and architectural complexity affects the benthic colonization?, in: Boutouil, M., Le Boulanger, S. (Eds.), Proceedings of the RECIFS Conference on Artificial Reefs: From Materials to Ecosystems. Caen, France, pp. 53-60.

Schaal, G., Riera, P., Leroux, C., Grall, J., 2010. A seasonal stable isotope survey of the food web associated to a peri-urban rocky shore. Mar. Biol. 157, 283-294. doi:DOI 10.1007/s00227009-1316-9

Schoener, T.W., 1974. Resource partitioning in ecological communities. Science 185, 27-39.

Svensson, J.R., Marshall, D.J., 2014. Limiting resources in sessile systems: food enhances diversity and growth of suspension feeders despite available space. Ecology. doi:10.1890/14-0665.1

Tiano, M., Tronczyński, J., Harmelin-Vivien, M., Tixier, C., Carlotti, F., 2014. PCB concentrations in plankton size classes, a temporal study in Marseille Bay, Western Mediterranean Sea. Mar. Pollut. Bull. 89, 331-339. doi:10.1016/j.marpolbul.2014.09.040

Topçu, N.., Perez, T., Grégori, G., Harmelin-Vivien, M., 2010. In situ investigation of Spongia officinalis (Demospongiae) particle feeding: Coupling flow cytometry and stable isotope analysis. J. Exp. Mar. Biol. Ecol. 389, 61-69.

Trussell, G.C., Lesser, M.P., Patterson, M.R., Genovese, S.J., 2006. Depth-specific differences in growth of the reef sponge Callyspongia vaginalis: role of bottom-up effects. Mar. Ecol. Prog. Ser. 323, 149-158. 
Vadeboncoeur, Y., Jeppesen, E., Zanden, M., Schierup, H., Christoffersen, K., Lodge, D.M., 2003. From Greenland to green lakes: cultural eutrophication and the loss of benthic pathways in lakes. Limnol. Oceanogr. 48, 1408-1418.

Ward, J.., Shumway, S.E., 2004. Separating the grain from the chaff: particle selection in suspensionand deposit-feeding bivalves. J. Exp. Mar. Biol. Ecol. 300, 83-130.

Xu, Q., Yang, H., 2007. Food sources of three bivalves living in two habitats of Jiaozhou Bay (Qingdao, China): indicated by lipid biomarkers and stable isotope analysis. J. Shellfish Res. 26, 561567.

Yakovis, E.L., Artemieva, A.V., Fokin, M.V., Varfolomeeva, M.A., 2012. Intraspecific variation in stable isotope signatures indicates no small-scale feeding interference between a horse mussel and an ascidian. Mar. Ecol.-Prog. Ser. 467, 113-120.

Yokoyama, H., Ishihi, Y., Yamamoto, S., 2008. Diet-tissue isotopic fractionation of the Pacific oyster Crassostrea gigas. Mar. Ecol. Prog. Ser. 358, 173-179.

Yokoyama, H., Tamaki, A., Harada, K., Shimoda, K., Koyama, K., Ishihi, Y., 2005a. Variability of diettissue isotopic fractionation in estuarine macrobenthos. Mar. Ecol.-Prog. Ser. 296, 115-128.

Yokoyama, H., Tamaki, A., Koyama, K., Ishihi, Y., Shimoda, K., Harada, K., 2005b. Isotopic evidence for phytoplankton as a major food source for macrobenthos on an intertidal sandflat in Ariake Sound, Japan. Mar. Ecol. Prog. Ser. 304, 101-116.

Zhao, L., Denis, M., Barani, A., Beker, B., Mante, C., Xiao, T., Gregori, G., 2012. Possible bloom of free trichomes in the Bay of Marseille, NW Mediterranean Sea: an anomaly evidenced by flow cytometry. J. Plankton Res. 34, 711-718. 
List of figures:

Fig. 1: Map of the sampling zone, with sampling sites identified with black stars. Bottom pictures represent a schematic view of the unitary cubic module and a picture of the whole "metal basket" artificial reef before its deployment (modified from Charbonnel et al., 2011).

Fig. 2: Seasonal variation of the isotopic ratios of suspension feeder groups resulting from clustering analyses. Stars represent the actual values measured for OM sources, uncorrected for trophic enrichment factor.

Fig.3: Seasonal variations (summer: left boxes with light border, winter: right boxes, hard border) of potential food source contribution to the diet of the four filter-feeders group issued from the clustering analysis. Boxes represent 50, 75 and $95 \%$ Bayesian credibility intervals, from light to dark grey. The point in the middle of each box is the mode of the distribution.

Fig. 4: Seasonal variation of $\delta^{13} \mathrm{C}$ mean values (squares) and ranges (dotted areas). Groups are vertically ordinated based on their $\delta^{15} \mathrm{~N}$ value (the highest position, the highest $\delta^{15} \mathrm{~N}$ ) but the relative position is not representative of the $\delta^{15} \mathrm{~N}$ difference between groups.

Fig. 5: Seasonal variation of the mean distance to centroid (CD, above panel) and of the mean distance to nearest neighbor (MNND, below panel). Color of the boxes stands for the season (black border, white background: summer, grey border and background: winter) 
Fig. 1:

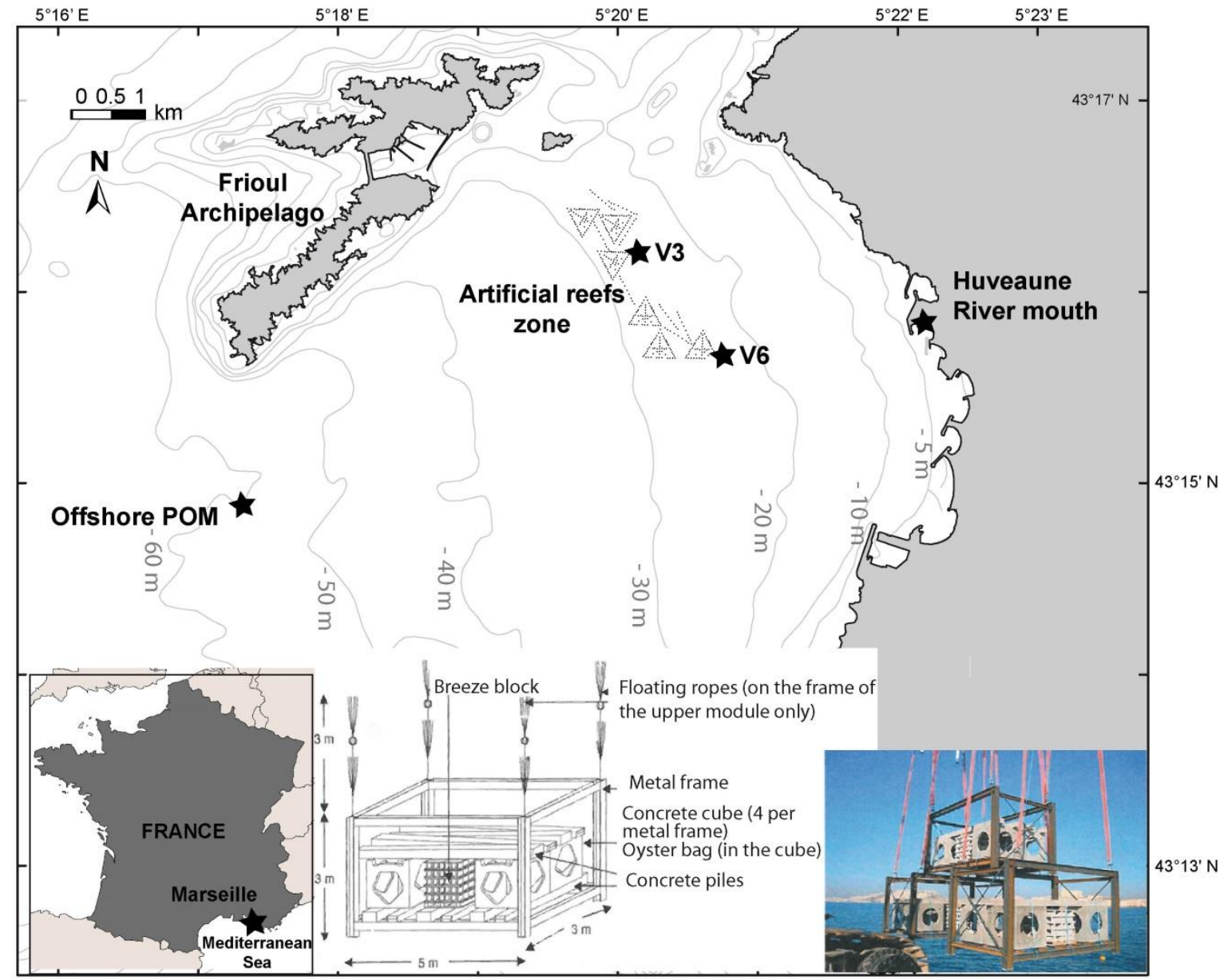


Fig. 2 (colored version, for online publication only):

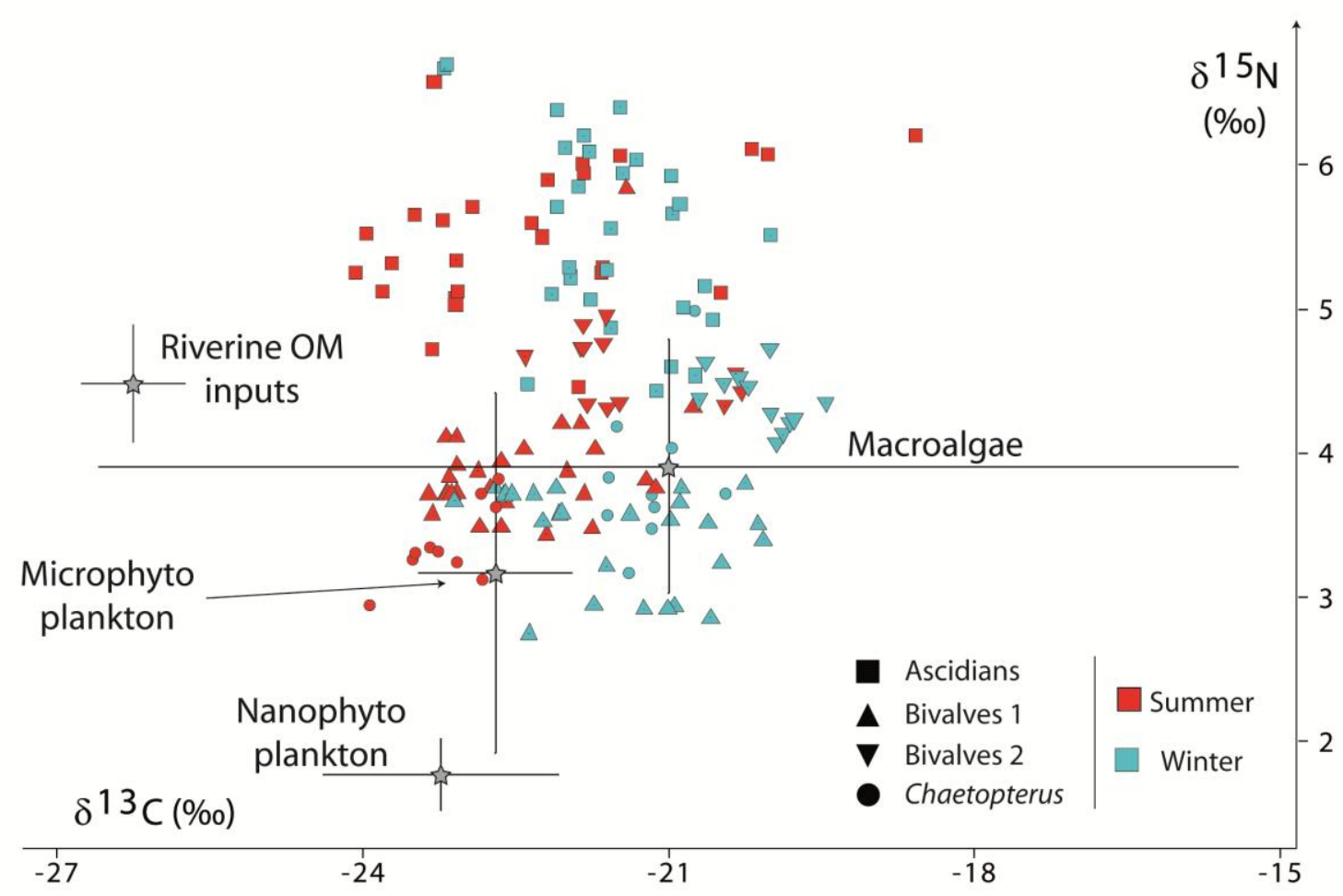


Fig. 2 (black and white version, for printed version only)

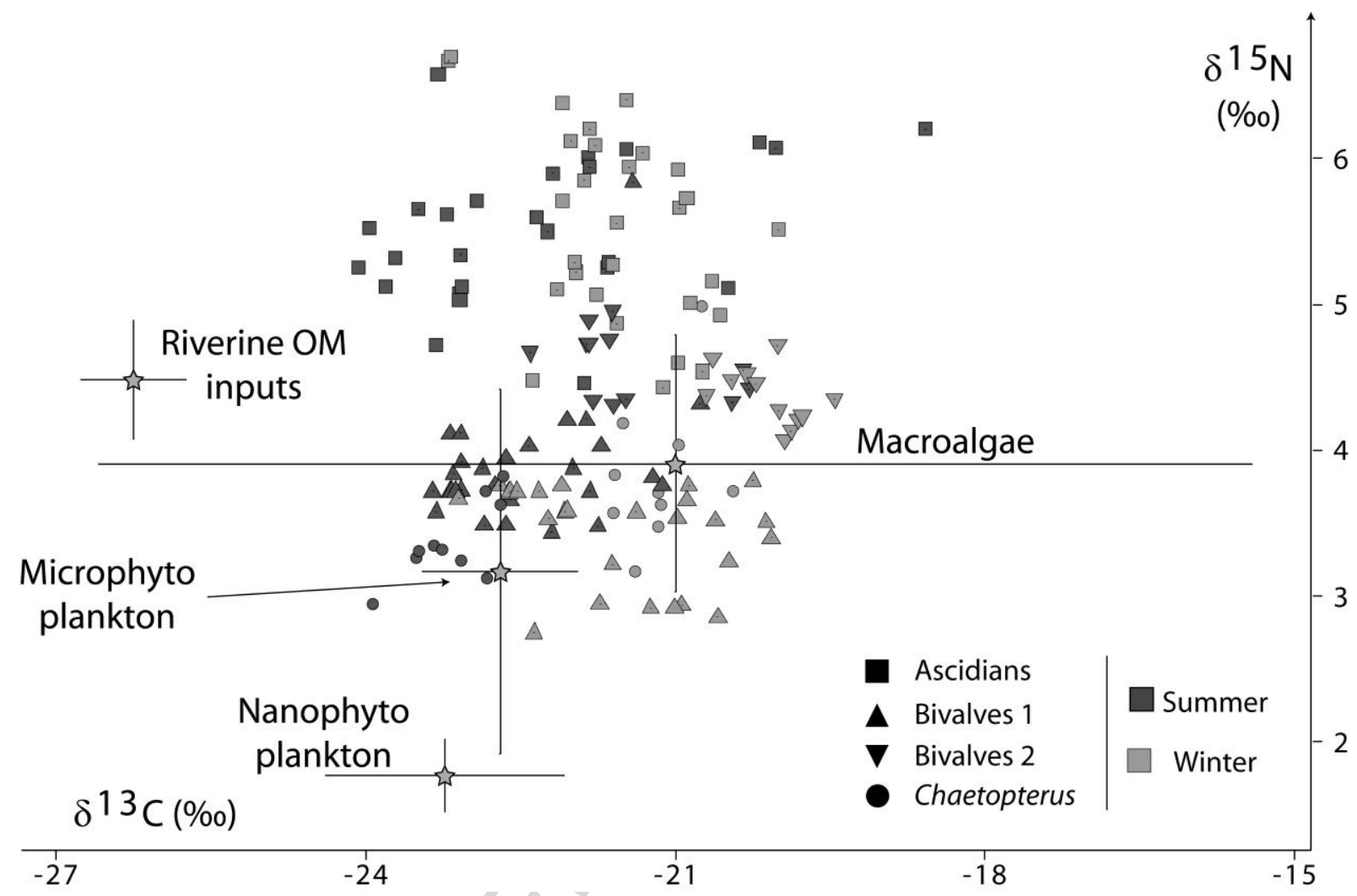


Fig. 3:
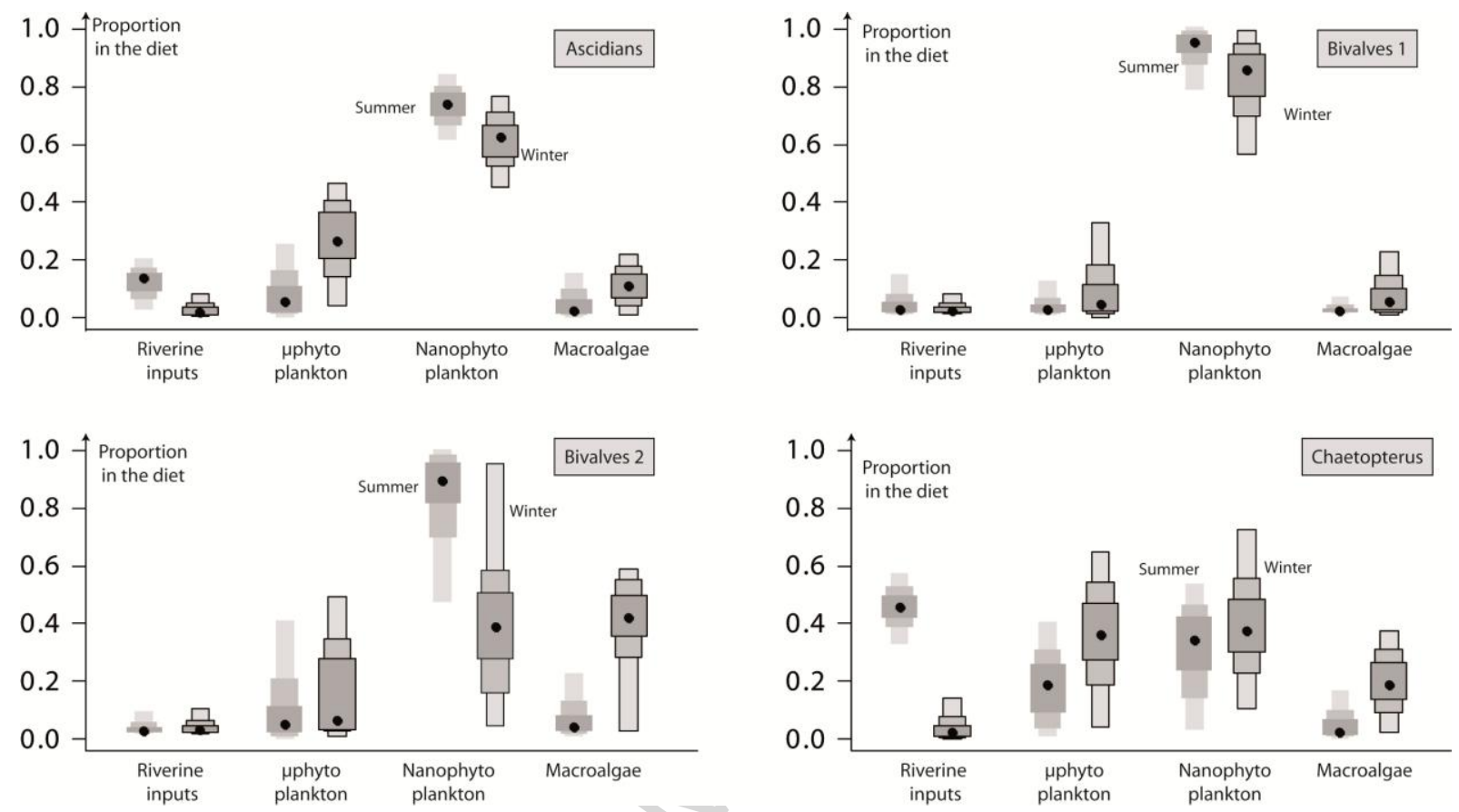
Fig. 4:

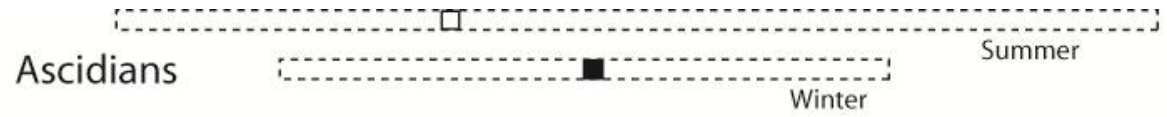

Bivalves 2

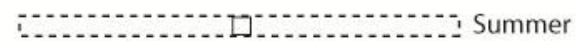

;

Winter

Bivalves 1 r

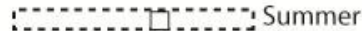

Chaetopterus

\begin{tabular}{rlllllll} 
& \multicolumn{4}{c}{$\delta^{13} \mathrm{C}(\% 0)$} \\
-25 & -24 & -23 & -22 & -21 & -20 & -19 & -18
\end{tabular}


Fig.5:

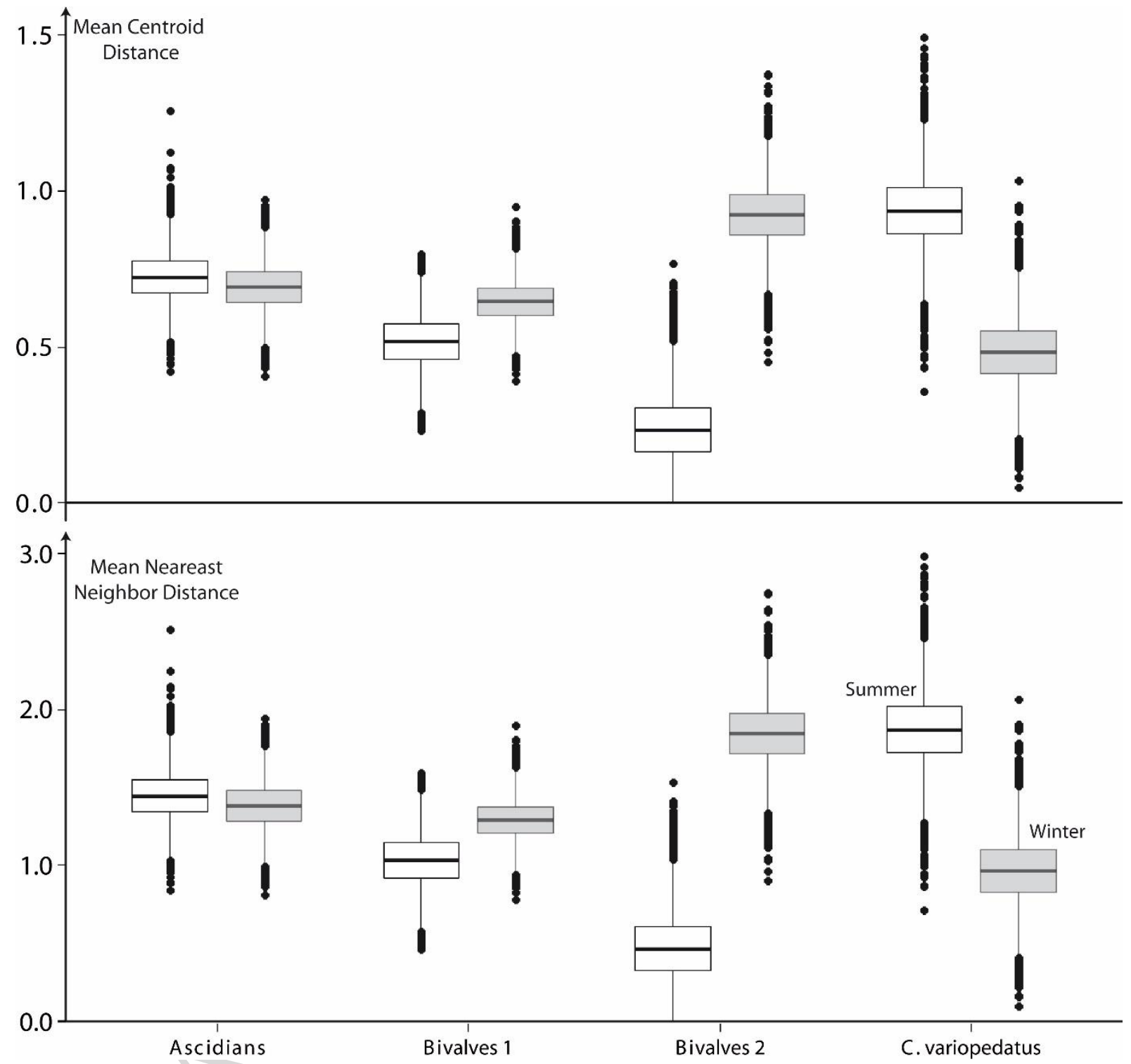


Tables

Table 1: Seasonal variation of isotopic ratios. $n$ SIA: number of stable isotope analyses

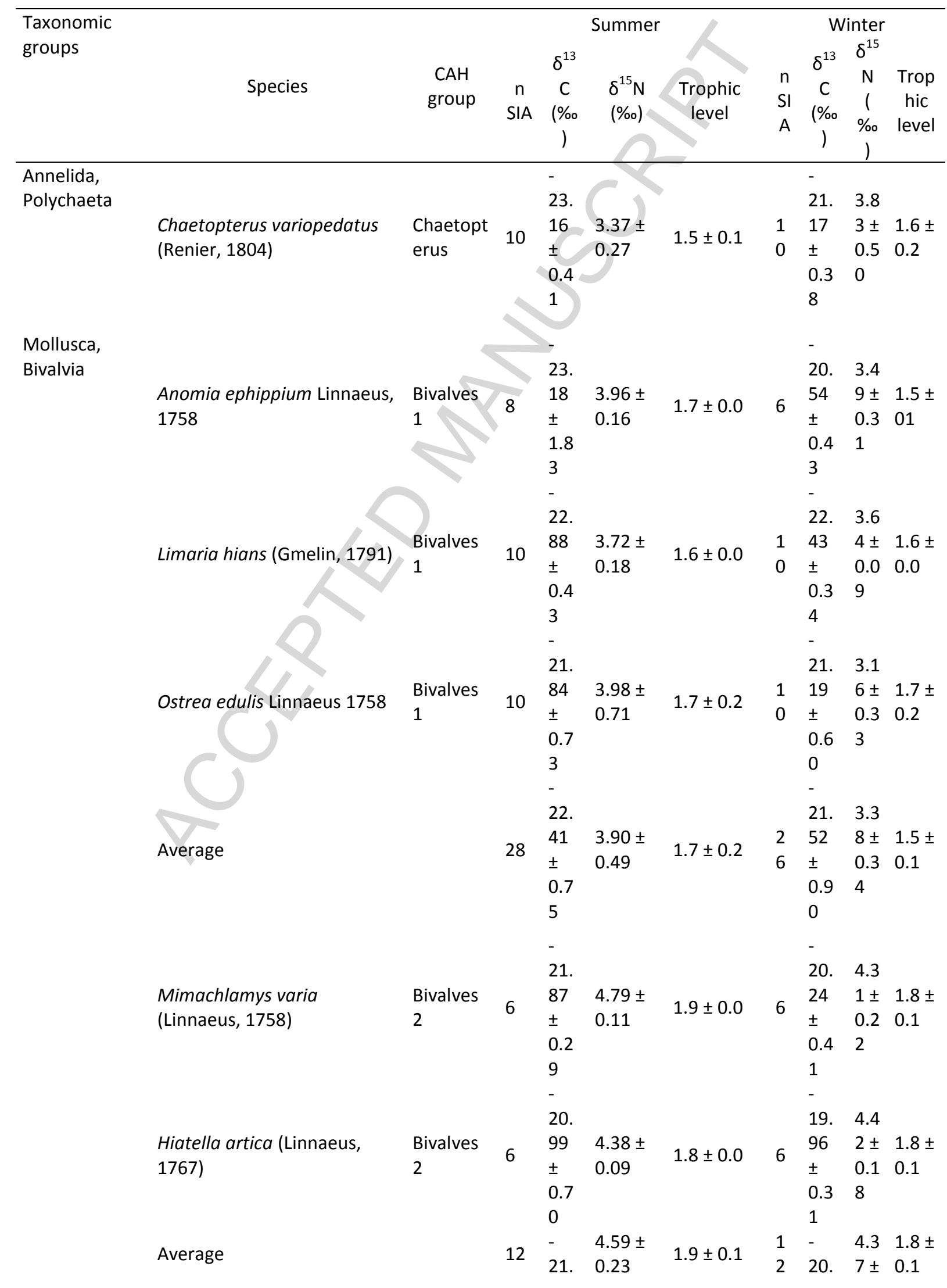




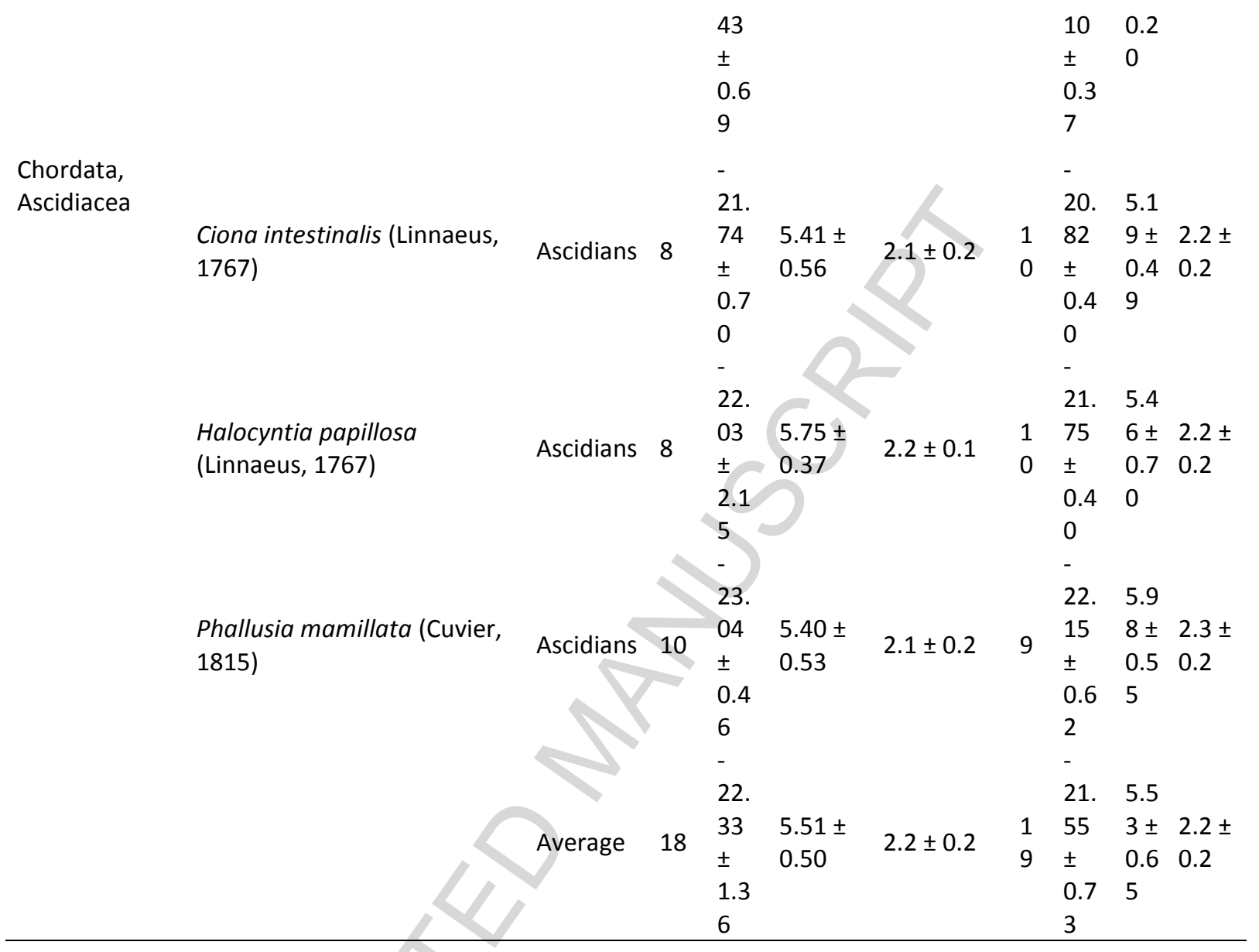


Table 2: SIAR Bayesian mixing model design

\begin{tabular}{|c|c|c|c|c|}
\hline OM source & $\begin{array}{c}\delta^{13} \mathrm{C} \\
\text { (mean } \pm \mathrm{sd})\end{array}$ & $\begin{array}{c}\delta^{15} \mathrm{~N} \\
(\text { mean } \pm \mathrm{sd})\end{array}$ & Explanation & Source \\
\hline Microphytoplancton & $-22.70 \pm 0.76 \%$ & $3.17 \pm 1.25 \%$ o & Cells size : > $10 \mu \mathrm{m}$ & (Darnaude et al., 2004) \\
\hline Nanophytoplancton & $-25.23 \pm 1.16 \%$ & $1.77 \pm 0.25 \%$ o & Cells size $: 2-10 \mu \mathrm{m}$ & (Rau et al., 1990) \\
\hline Macroalgae & - $21.09 \pm 2.41 \%$ & $3.74 \pm 0.81 \%$ & $\begin{array}{l}\text { Average values measured for } \\
18 \text { species }\end{array}$ & $\begin{array}{l}\text { present study ; (Cresson } \\
\text { et al., 2014) }\end{array}$ \\
\hline Terrigenous inputs & $-26.25 \pm 0.51 \%$ & $4.48 \pm 0.41 \%$ o & $\begin{array}{l}\text { Average value of } 4 \text { sampling } \\
\text { during flooding events }\end{array}$ & $\begin{array}{l}\text { present study; (Cresson } \\
\text { et al., 2012) }\end{array}$ \\
\hline $\begin{array}{l}\text { Trophic enrichment } \\
\text { factors }\end{array}$ & $1.28 \pm 0.72$ & $3.25 \pm 0.67$ & \multicolumn{2}{|c|}{$\begin{array}{l}\text { Calculated as the average of several values used in the } \\
\text { literature }\end{array}$} \\
\hline
\end{tabular}


Table 3: Interspecific and spatio-temporal variations of filter-feeders isotopic ratios. Results of the post-hoc mean comparison tests are provided in the last column, with the names of the groups abbreviated

\begin{tabular}{|c|c|c|c|c|}
\hline & Factor & Stats & $p$-value & post hoc \\
\hline \multirow[t]{7}{*}{$\delta^{13} \mathrm{C}$} & Group & $F_{(3,136)}=14.82$ & $<0.0001$ & Chaeto $=$ Ascid $=$ Biv1 $<$ Biv2 \\
\hline & Season & $F_{(1,136)}=69.83$ & $<0.0001$ & Summer $<$ Winter \\
\hline & Site & $F_{(1,136)}=0.965$ & 0.33 & ns \\
\hline & Group x Season & $\mathrm{F}_{(3,136)}=2.95$ & 0.03 & ns \\
\hline & Group x Site & $F_{(3,136)}=2.29$ & 0.08 & ns \\
\hline & Site $\times$ Season & $F_{(1,136)}=1.79$ & 0.18 & ns \\
\hline & Group $x$ Site $x$ Season & $F_{(3,136)}=1.13$ & 0.34 & ns \\
\hline \multirow[t]{7}{*}{$\delta^{15} \mathrm{~N}$} & Group & $F_{(3,125)}=165.70$ & $<0.0001$ & Chaeto $=$ Biv $1<$ Biv $2<$ Ascid \\
\hline & Season & $\mathrm{F}_{(1,125)}=1.21$ & 0.27 & ns \\
\hline & Site & $F_{(1,125)}=3.71$ & 0.06 & ns \\
\hline & Group $x$ Season & $\mathrm{F}_{(3,125)}=4.79$ & 0.03 & ns \\
\hline & Group x Site & $F_{(3,125)}=0.15$ & 0.93 & ns \\
\hline & Site $x$ Season & $\mathrm{F}_{(1,125)}=0.35$ & 0.56 & ns \\
\hline & Group x Site x Season & $F_{(3,125)}=0.55$ & 0.64 & ns \\
\hline
\end{tabular}


Table 4: Summary of the seasonal trends observed for the 5 isotopic metrics considered. Sum: summer, Win: winter.

\begin{tabular}{llllll}
\hline Group & $\delta^{13} \mathrm{C}$ range & SEAb & TA & CD & MNND \\
\hline Ascidians & Sum $>$ Win & Sum $>$ Win & Sum $>$ Win & Sum $>$ Win & Sum $>$ Win \\
Bivalve 1 & Sum $<$ Win & Sum $<$ Win & Sum $>$ Win & Sum $<$ Win & Sum $<$ Win \\
Bivalve 2 & Sum $>$ Win & Sum $>$ Win & Sum $>$ Win & Sum $<$ Win & Sum $<$ Win \\
Chaetopterus & Sum $>$ Win & Sum $<$ Win & Sum $<$ Win & Sum $>$ Win & Sum $>$ Win \\
\hline
\end{tabular}




\section{Graphical abstract}

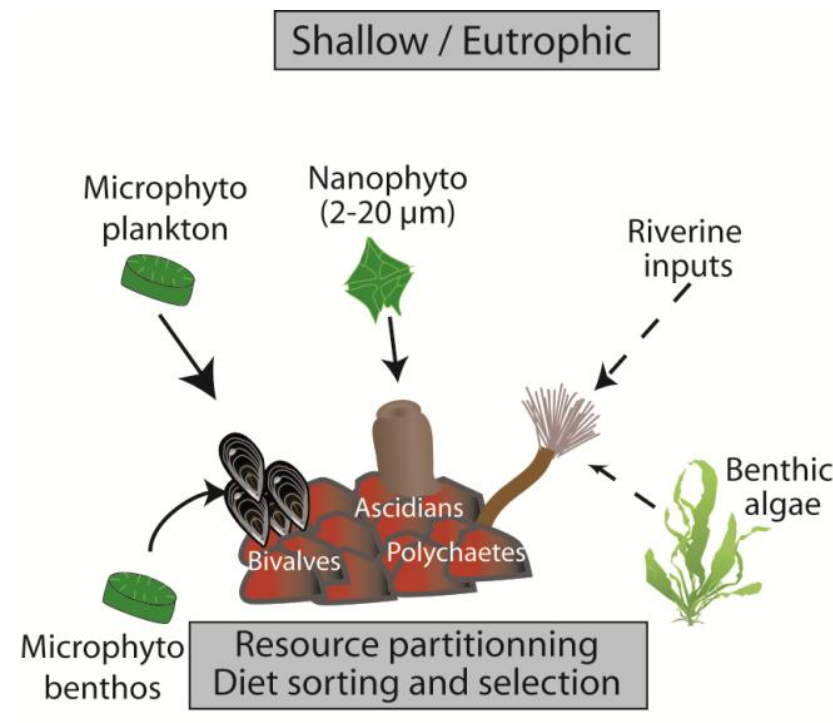

Deep - Oligotrophic

Nano \& pico-

plankton Diazotrophic Riverine

Microphyto bacteria? inputs

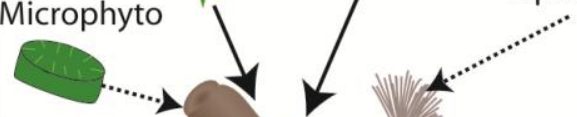

